\title{
FAKTOR-FAKTOR ANTESEDEN PENENTU KEPUASAN PASIEN DI PUSKESMAS MLATI II
}

\author{
Budi Hermawan \\ hermawanbudi92@yahoo.co.id \\ Universitas Ahmad Dahlan \\ Sukardi \\ sukardi_feuad@yahoo.com \\ Universitas Ahmad Dahlan
}

\begin{abstract}
ABSTRAK
The study entitled "Antecedent Factors Determining Patient Satisfaction In Mlati II Health Center " aims to partially determine the effect and simultaneous variables of caring, effectiveness on an ongoing basis, appropriateness/worthiness, information, efficiency, effectiveness-food to satisfaction patients at Mlati II Health Center. The population in this study was inpatients who use the services of Mlati II Health Center. The sampling technique at this research uses purposive sampling. Data collection technique using interviews and questionnaires. 87 samples were processed from 100 respondent. The data analysis method used is linear regression analysis multiple. Testing the variables in this study using the help of the program SPSS 16.0 for windows. By using the method of multiple linear regression can be concluded that the caring variable does not significantly influence satisfaction patient. The effectiveness variable on an ongoing basis also has no significant effect. The appropriateness/feasibility variable has no significant effect. Information variable significant effect. The efficiency variable has no significant effect. Variable food-effectiveness has no significant effect. Simultaneously the variable Concern (X1), Effectiveness on an on going basis (X2), Appropriateness/Feasibility (X3), Information (X4), Efficiency (X5), FoodEffectiveness (X6) have no effect significant on patient satisfaction. The resulting coefficient of determination is equal to 0.008 which means $0.8 \%$ can explain the variable Concern (X1), Sustained effectiveness (X2), Appropriateness/Feasibility (X3), Information (X4), Efficiency (X5), food-effectiveness (X6) and patient satisfaction (Y) together, while the remaining $92 \%$ is explained by other variables not examined.
\end{abstract}

Keywords: Respect and Caring, Effectiveness and Continuity, Appropriateness, Information, Efficiency, Effectiveness-Meals and Patient Satisfaction.

\section{PENDAHULUAN}

Kesehatan adalah salah satu kebutuhan pokok dan juga merupakan faktor penting yang mempengaruhi produktivitas dan kualitas sumber daya manusia. Pelayanan kesehatan yang bermutu dengan pembiayaan yang efisien menjadi pilihan masyarakat saat ini. Sebagai konsekuensinya konsumen saat ini setiap pemberi pelayanan kesehatan dituntut untuk bisa memberikan pelayanan yang berkualitas agar dapat menarik pelanggan. Namun hal ini berbeda jika dipandang dari segi masyarakat sebagai pihak yang menggunakan jasa pelayanan tersebut, dimana biaya pelayanan kesehatan menjadi salah satu faktor penentu utilisasi terhadap pelayanan kesehatan. Pembangunan kesehatan adalah bagian dari pembangunan nasional yang bertujuan meningkatkan kesadaran, kemauan dan kemampuan untuk hidup sehat bagi 
setiap orang agar terwujud. Pembangunan kesehatan merupakan upaya seluruhwarga negara Indonesia, tidak hanya oleh perorangan, tetapi juga keluarga, masyarakat swasta maupun pemerintah.

Dalam upaya mewujudkan status kesehatan masyarakat yang optimal, berbagai upaya harus dilakukan, salah satu di antaranya adalah dengan menyelengaraakan pelayanan kesehatan. Penyelenggaraan pelayanan kesehatan untuk masyarakat ditingkat dasar di Indonesia adalah melalui Pusat Kesehatan Masyarakat (Puskesmas) yang merupakan unit organisasi serta unit fungsional dari Dinas Kesehatan Kabupaten/Kotamadya dan diberi tanggung jawab sebagai pengelola, contoh dan juga pelopor kesehatan bagi masyarakat tiap wilayah kecamatan dari Kabupaten/Kotamadya.

Dalam Wulandari (2011) kualitas pelayanan merupakan indikator kinerja bagi penyelenggara pelayanan kesehatan seperti Puskesmas. Puskesmas akan semakin maju jika kinerjanya dapat dipertahankan. Oleh karena itu pelayanan Puskesmas harus berubah mengarah pada kekuatan pasar sehingga orientasi Puskesmas bergeser dari organisasi sosial ke arah sosio ekonomi, dengan demikian mempertahankan pelanggan adalah tujuan yang harus dicapai. Pemerintah melalui Keputusan Menteri Kesehatan Republik Indonesia Nomor 228 / MENKES / SK / III / 2002 tentang pedoman penyusunan standar pelayanan minimal Rumah Sakit/Puskesmas yang wajib dilaksanakan daerah, telah memberikan standar layanan minimal yang harus dilaksanakan Rumah Sakit/Puskesmas. Salah satu tujuan dari standar layanan minimal Rumah Sakit/Puskesmas tersebut adalah terlaksananya layanan yang bermutu oleh Rumah Sakit/Puskesmas diperuntukkan bagi masyarakat.

Menurut Lupiyoadi (2014) menjadi organisasi yang berfokus pada konsumen adalah pilihan strategis bagi industri dan dunia usaha agar mampu bertahan ditengah situasi lingkungan ekonomi yang memperlihatkan kecenderungan, seperti: fluktuasi curam, perubahan demi perubahan, persaingan tinggi dan semakin canggihnya kualitas hidup. Salah satu cara adalah dengan menciptakan kepuasan pelanggan (customer satisfaction) melalui peningkatan kualitas, karena pelanggan adalah fokus utama ketika kita mengungkap tentang kepuasan dan kualitas jasa.

Melihat uraian di atas, di dalam penelitian ini saya sebagai peneliti merasa tertarik untuk melakukan penelitian mengenai Faktor-Faktor Anteseden Penentu Kepuasan Pasien Di Puskesmas Mlati II. Dimana untuk referensi penelitian saya menggunakan jurnal yang berjudul The Dimensions of Service Quality for Hospital; Development and Use of the KQCAH Scale. Di dalam jurnal Sower (2001) tersebut terdapat enam dimensi kualitas pelayanan yaitu: Rasa kepedulian, Efektivitas secara berkelanjutan, Kepantasan/kelayakan, Informasi, Efisiensi, Efektivitas-makanan.

\section{REVIEW LITERATUR DAN HIPOTESIS}

\section{Landasan Teori}

1. Kepuasan Pelanggan

Menurut Engel et al., dalam Tjiptono (2006) menyatakan bahwa kepuasan pelanggan merupakan evaluasi purnabeli dimana alternatif yang dipilih sekurang-kurangnya sama atau melampaui harapan pelanggan, sedangkan ketidakpuasan timbul apa bila hasil (outcome) tidak memenuhi harapan.

\section{Rasa Kepedulian (Respect \& Caring)}

Secara umum dapat diartikan sebagi suatu kemampuan untuk berdedikasi bagi orang lain, pengawasan dengan waspada, serta suatu perasaan empati pada orang lain dan perasaan cinta atau menyayangi. Caring merupakan fenomena universal 
yang mempengaruhi bagaimana seseorang berpikir, merasakan dan berperilaku dalam hubungannya dengan orang lain.

3. Efektivitas Secara Berkelanjutan (Effectiveness \& Continuity)

Merupakan pemanpaatan sumber daya, sarana dan prasarana dalam jumlah tertentu yang secara sadar ditetapkan sebelumnya untuk menghasilkan sejumlah pekerjaan tepat pada waktunya.

\section{Kepantasan (Appropriateness)}

Dimensi kepantasan kelayakan tidak berpengaruh langsung dengan efektivitas layanan kesehatan, tetapi mempengaruhi kepuasan pasien / konsumen sehingga mendorong pasien untuk datang berobat kembali ke tempat tersebut. Kepantasan dan kelayakan dapat menimbulkan kepercayaan diri pada pasien terhadap organisasi pada pelayanan kesehatan tersebut.

\section{Informasi (Information)}

Layanan kesehatan yang bermutu harus mampu memberikan informasi yang jelas tentang apa,siapa, kapan, dimana dan bagaimana layanan kesehatan itu akan atau telah dilaksanakan. Sistem dimensi informasi ini sangat penting pada tingkat puskesmas baik dari daerahdaerah maupun untuk tingkat rumah sakit yang lainnya.

\section{Efisiensi (Efficiency)}

Sumber daya kesehatan sangat terbatas. Oleh karena itu dimensi efisiensi kesehatan sangat penting dalam layanan kesehatan. Layanan kesehatan yang efisien dapat melayani lebih banyak pasien dan masyarakat. Layanan kesehatan yang tidak efisien umumnya berbiaya mahal, kurang nyaman bagi pasien, memerlukan waktu lama dan menimbulkan resiko yang lebih besar pada pasien. Dengan melakukan analisis efisiensi dan efektivitas kita dapat memilih intervensi yang paling efisien.

\section{Efektivitas-Makanan (Effectiveness- Meals)}

Penyelenggaraan makanan merupakan salah satu dari kegiatan pokok yang ada di Puskesmas. Penyelenggaraan makanan merupakan suatu rangkaian kegiatan mulai dari perencanaan menu sampai dengan pendistribusian makanan kepada pasien. Pelayanan Gizi Puskesmas adalah subsistem pelayanan kesehatan paripurna yang ada di Puskesmas yang merupakan rangkaian komponen kerja yang saling terkait dalam mencapai tujuan yang telah ditetapkan bersama.

\section{Penelitian Terdahulu}

Djunaidi (2006) penelitian tentang analisis kepuasan konsumen menunjukkan nilai persepsi pelanggan secara keseluruhan, didapatkan angka -3,36. Dari hasil perhitungan didapatkan nilai gap kriteria pelayanan tertinggi adalah pelayanan pemeriksaan, pengobatan, dan perawatan yang tepat -3,2. Nilai gap dimensi kualitas jasa pelayanan tertinggi adalah reliability sebesar -3,2. Hal ini menunjukkan bahwa kepuasan pengguna jasa pelayanan di Puskesmas Kerjo terhadap pelayanan yang saat ini diberikan masih belum tercapai.

Supardi (2008) analisis data dilakukan secara bertahap mencakup analisis univariat untuk menghitung distribusi frekuensi, proporsi, nilai ratarata, median, modus, analisis bivariat untuk menilai hubungan antara variabel independen dan variabel dependen menggunakan uji Chi-square, dan analisis multivariate untuk mengetahui faktorfaktor yang berhubungan dengan kepuasan pasien Puskesmas menggunakan uji 
regresi logistik berganda menunjukkan distribusi pasien rawat inap di Puskesmas berdasarkan kepuasan. Kepuasan pasien rawat inap di Puskesmas dalam hal lama waktu menunggu, keramahan petugas, kejelasan informasi, keikutsertaan mengambil keputusan pengobatan, kepercayaan terhadap petugas, kebebasan memilih tempat berobat, kebersihan ruangan pengobatan dan kemudahan dikunjungi oleh keluarga atau teman mencapai rata-rata skor $0,74(0,69-0,78)$ yang termasuk kategori cukup memuaskan.

\section{Hipotesis}

H1: Diduga ada pengaruh rasa kepedulian terhadap kepuasan pasien di Puskesmas Mlati II.

H2: Diduga ada pengaruh efektivitas secara berkelanjutan terhadap kepuasan pasien di Puskesmas Mlati II.

H3: Diduga ada pengaruh Kepantasan / Kelayakan terhadap kepuasan pasien di Puskesmas Mlati II.

H4: Diduga ada pengaruh informasi terhadap kepuasan pasien di Puskesmas Mlati II.

H5: Diduga ada pengaruh efisiensi terhadap kepuasan pasien di Puskesmas Mlati II.

H6: Diduga ada pengaruh efektivitasmakanan terhadap kepuasan pasien di Puskesmas Mlati II.

\section{METODE PENELITIAN}

\section{Populasi dan Sampel}

Menurut Sugiyono (2014) menyatakan bahwa populasi adalah wilayah generalisasi yang terdiri atas objek/subjek yang mempunyai kualitas dan karakteristik tertentu yang ditetapkan oleh peneliti untuk dipelajari dan kemudian ditarik kesimpulannya. Dengan demikian populasi dalam penelitian ini adalah seluruh pasien rawat inap Puskesmas Mlati II mulai pada tanggal 10 april - 7 mei 2015 .

$$
\text { Menurut Sugiyono }
$$
menyatakan bahwa sampel adalah bagian dari jumlah dan karakteristik yang dimiliki oleh populasi tersebut. Sampel dalam penelitian ini yaitu Pasien yang menjalani rawat inap di Puskesmas Mlati II milai tanggal 10 April - 7 Mei 2015.

\section{Definisi Operasional}

1. Variabel Independen

a. Rasa Kepedulian

Rasa kepedulian secara umum dapat diartikan sebagi suatu kemampuan untuk berdedikasi bagi orang lain, pengawasan dengan waspada, serta suatu perasaan empati pada orang lain dan perasaan cinta atau menyayangi. Peduli (caring) merupakan fenomena universal yang mempengaruhi bagaimana seseorang berpikir, merasakan dan berperilaku dalam hubungannya dengan orang lain.

b. Efektifitas Secara Berkelanjutan Efektifitas

secara berkelanjutan merupakan pemanfaatan sumber daya, sarana dan prasarana dalam jumlah tertentu yang secara sadar ditetapkan sebelumnya untuk menghasilkan sejumlah pekerjaan tepat pada waktunya.

c. Kepantasan/Kelayakan

Dimensi kepantasan kelayakan tidak berpengaruh langsung dengan efektivitas layanan kesehatan, akan tetapi mempengaruhi kepuasan pasien / konsumen sehingga mendorong pasien untuk datang berobat kembali ke tempat tersebut. Kepantasan dan kelayakan dapat menimbulkan kepercayaan diri pada pasien terhadap organisasi pada pelayanan kesehatan tersebut. 
d. Informasi

Layanan kesehatan yang bermutu harus mampu memberikan informasi yang jelas tentang apa, siapa, kapan, dimana dan bagaimana layanan kesehatan itu akan atau telah dilaksanakan. Sistem dimensi informasi ini sangat penting pada tingkat puskesmas baik dari daerahdaerah maupun untuk tingkat rumah sakit yang lainnya.

e. Efisiensi

Efisiensi sumber daya kesehatan sangat terbatas. Oleh karena itu dimensi efisiensi kesehatan sangat penting dalam layanan kesehatan. Layanan kesehatan yang efisien dapat melayani lebih banyak pasien dan masyarakat. Layanan kesehatan yang tidak efisien umumnya berbiaya mahal, kurang nyaman bagi pasien, memerlukan waktu lama dan menimbulkan resiko yang lebih besar pada pasien. Dengan melakukan analisis efisiensi dan efektivitas kita dapat memilih intervensi yang paling efisien.

f. Efektifitas Makanan

Penyelenggaraan makanan merupakan salah satu dari kegiatan pokok yang ada di Puskesmas. Penyelenggaraan makanan merupakan suatu rangkaian kegiatan mulai dari perencanaan menu sampai dengan pendistribusian makanan kepada pasien. Pelayanan Gizi Puskesmas adalah sub sistem pelayanan kesehatan paripurna yang ada di Puskesmas yang merupakan rangkaian komponen kerja yang saling terkait dalam mencapai tujuan yang telah ditetapkan bersama.

\section{Variabel Dependen}

Variabel dependen (Y) yang digunakan dalam penelitian ini adalah Kepuasan Pelanggan (Pasien). Menurut Engel et al., dalam Tjiptono (2006) menyatakan bahwa kepuasan pelanggan merupakan evaluasi purnabeli dimana alternatif yang dipilih sekurangkurangnya sama atau melampaui harapan pelanggan, sedangkan ketidakpuasan timbul apa bila hasil (outcome) tidak memenuhi harapan.

\section{Uji Instrumen}

\section{Uji Validitas}

Menurut Sugiyono (2014) uji keabsahan data dalam penelitian, sering hanya ditekankan pada uji validitas dan reliabilitas. Dalam penelitian kuantitatif, kriteria utama terhadap data hasil penelitian adalah valid, reliabel dan obyektif. Validitas merupakan derajat ketepatan antara data yang terjadi pada obyek penelitian dengan daya yang dapat dilaporkan oleh peneliti. Dengan demikian data yang valid adalah data "yang tidak berbeda" antara data yang dilaporkan oleh peneliti dengan data yang sesungguhnya terjadi pada obyek penelitian. Kalau dalam obyek penelitian terdapat warna merah, maka penelitian akan melaporkan warna merah, kalau dalam obyek penelitian para pegawai bekerja dengan keras, maka peneliti melaporkan bahwa pegawai bekerja dengan keras. Bila peneliti membuat laporan yang tidak sesuai dengan apa yang terjadi pada obyek, maka data tersebut dapat dinyatakan tidak valid.

Pengujian validitas yang dilakukan adalah construct validity dengan metode confirmatory factor analysis yang dilakukan dengan bantuan program SPSS. Analisis faktor digunakan dalam penelitian ini karena merupakan salah satu metode statistik multivariate yang tujuan utamanya untuk meringkas atau mengurangi data atau variabel yang akan diperlukan untuk dianalisis. Analisis faktor memecahkan masalah yang menyangkut hubungan timbal balik antara sejumlah indikator dan kemudian menjelaskan keterkaitan 
antar indikator ke dalam dimensidimensi yang mendasari hubungan tersebut. Karena item-item pertanyaan dalam kuesioner diadopsi dari penelitian sebelumnya dengan dimodifikasi maka analisis faktor yang dilakukan bersifat confirmatory, yaitu saat pengolahan pada tahap extraction dipilih number of factor adalah 7 sesuai dengan variabel yang diuji dalam model penelitian.

Menurut Hair et al., (1998) kriteria signifikansi terhadap item-item pertanyaan dalam penelitian ini didasarkan pada signifikansi praktis (practical significance) seperti pada tabel berikut ini:

Signifikansi Faktor Loading

\begin{tabular}{|c|c|}
\hline Faktor Loading & Keterangan \\
\hline Lebih besar dari 0.30 & Level minimal \\
\hline Lebih besar dari 0.40 & Sangat penting \\
\hline Lebih besar dari 0.50 & Signifikan \\
\hline
\end{tabular}

Pedoman umum yang dipakai adalah semakin besar factor loading semakin penting indikator tersebut dalam menafsirkan suatu faktor. Itemitem yang mempunyai factor loading kurang dari 0.40 akan dikeluarkan karena dianggap hanya mempunyai kemampuan menafsirkan suatu faktor pada level minimum. Sedangkan item yang mempunyai factor loading lebih besar dari 0.40 dianggap signifikan dan bisa dimasukkan sebagai anggota suatu faktor.

2. Uji Reliabilitas

Menurut Susan Stainback dalam Sugiyono (2014:267) menyatakan bahwa Reabilitas berkenaan dengan derajad konsistensi dan stabilitas data atau temuan. Dalam pandangan positivistik (kuantitatif), suatu data dinyatakan reliabel apabila dua atau lebih peneliti dalam obyek yang sama menghasilkan data yang sama, atau peneliti sama dalam waktu berbeda menghasilkan data yang sama, atau sekelompok data bila dipecah menjadi dua menunjukkan data yang tidak berbeda. Kalau peneliti satu menemukan dalam obyek berwarna merah, maka peneliti yang lain juga demikian. Karena reliabilitas berkenaan dengan derajad konsistensi, maka bila ada peneliti lain mengulangi atau mereplikasi dalam penelitian pada obyek yang sama dengan metode yang sama maka akan menghasilkan data yang sama.

Pengujian instrumen penelitian dengan sampel sejumlah 30 responden. Koefisien reliabilitas ditunjukan oleh koefisien cronbach alpha yang berkisar antara 0 sampai 1 .Semakin tinggi nilai koefisien cronbach alpha berarti semakin tinggi reliabilitas alat ukur yang digunakan. Untuk menguji reliabilitas dalam penelitian ini adalah dengan membandingkan cronbach coefficient alpha ( $\mathrm{r}$ alpha) pada hasil olahan SPSS Release 16.0 dengan rule of thumb atau kesepakatan umum dari koefisien alpha yaitu lebih besar dari 0.6 untuk penelitian eksploratori.

\section{Teknik Analisis Data}

1. Analisis Regresi Berganda

Menurut Algifari (2014) model regresi linear untuk menganalisis hubungan pengaruh suatu variabel independen numerik (X) terhadap variabel dependen (Y) dalam mengukur skala interval dan skala rasio. Model regresi tersebut kemudian digunakan untuk menentukan taksiran nilai variabel dependen $(\mathrm{Y})$ pada nilai variabel independen (X) tertentu. Penerapan model regresi dalam banyak praktik membutuhkan suatu model regresi estimasi yang dapat digunakan untuk menghasilkan nilai estimasi yang menggunakan lebih dari satu variabel independen $(\mathrm{X})$.Artinya nilai variabel dependen (Y) tidak hanya dipengaruhi oleh satu variabel independen (X) saja.

Analisis regresi linear berganda digunakan untuk mengetahui seberapa 
besar pengaruh hubungan variabel Rasa kepedulian (X1), Efektivitas secara berkelanjutan (X2), Kepantasan I Kelayakan (X3), Informasi (X4), Efisiensi (X5), Efektivitas-Makanan (X6) terhadap variabel dependen kepuasan pasien (Y). Persamaan regresi yang dipakai adalah sebagai berikut:

$\mathrm{Y}: \mathrm{a}+\mathrm{b} 1 \mathrm{X} 1+\mathrm{b} 2 \mathrm{X} 2+\mathrm{b} 3 \mathrm{X} 3+\mathrm{b} 4 \mathrm{X} 4+$ b5X5 + b6X6

Keterangan:

Y : Kepuasan Pelanggan (Pasien)

a : Konstanta

b1-b6 : Koefisien Independen

X1 : Rasa Kepedulian

$\mathrm{X} 2$ : Efektivitas Secara Berkelanjutan

X3 : Kepantasan / Kelayakan

$\mathrm{X} 4$ : Informasi

$\mathrm{X} 5$ : Efisiensi

X6 : Efektivitas Makanan

\section{Uji Hipotesis}

\section{Uji Parsial (Uji T)}

Menurut Suharyadi (2010) uji signifikansi parsial atau individual digunakan untuk menguji apakah suatu variabel bebas berpengaruh atau tidak terhadap variabel terikat.

\section{Uji Simultan (Uji F)}

Menurut Suharyadi (2010) uji global disebut juga uji signifikansi serentak atau uji F. Uji ini dimaksudkan untuk melihat kemampuan menyeluruh dari variabel bebas (X1, X2,..Xn) dapat atau mampu menjelaskan tingkah laku atau keragaman variabel terikat (Y).

\section{Uji Koefisien Determinasi}

Menurut Suharyadi (2010) koefisien determinasi merupakan ukuran untuk mengetahui kesesuaian atau ketepatan anatara nilai dugaan atau garis regresi dengan data sampel. Jika semua data observasi terletak pada garis regresi akan diperoleh garis regresi yang sesuai atau sempurna, namun apabila data observasi tersebar jauh dari nilai dugaan atau garis regresinya, maka nilai dugaan menjadi kurang sesuai. Inti dari koefisien determinasi adalah bagian dari keragaman total variabel terikat $\mathrm{Y}$ (variabel yang dipengaruhi atau dependen) yang dapat diterangkan atau diperhitungkan oleh keragaman variabel bebas $\mathrm{X}$ (variabel yang mempengaruhi atau independen).

\section{HASIL PENELITIAN DAN PEMBAHASAN}

\section{Hasil Penelitian}

1. Hasil Uji Validitas

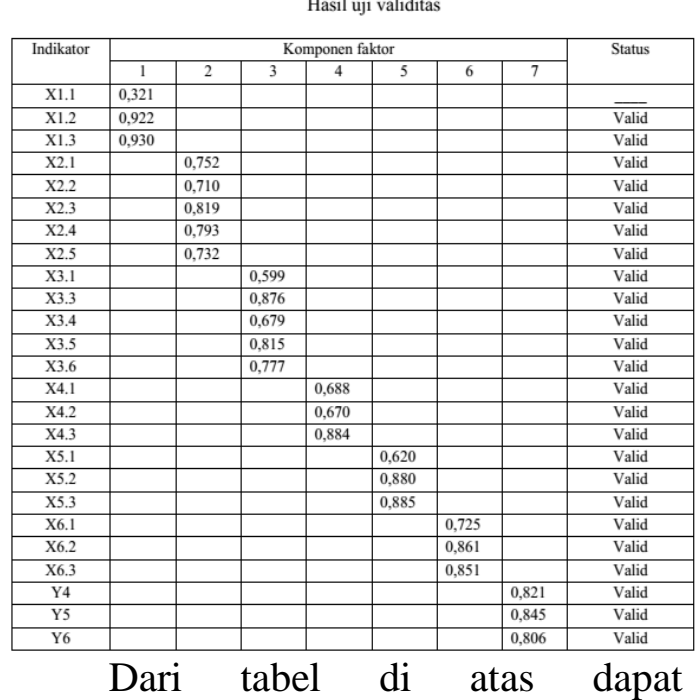
disimpulkan bahwa dalam pengujian validitas dan reliabilitas instrumen penelitian menggunakan tryout terlebih dahulu terhadap 30 responden. Dalam perhitungan, peneliti menggunakan bantuan komputer program SPSS release 16.00 for windows.

a. Uji validitas variabel rasa kepedulian $\mathrm{X} 1$

Tabel Component Matrix pada hasil output SPSS terlihat bahwa tabel terbentuk 1 komponen, yang 
artinya indikator X1.1, X1.2, dan X1.3 dikatakan valid dan hanya menjelaskan faktor rasa kepedulian.

b. Uji validitas variabel efektivitas secara berkelanjutan X2

Tabel Component Matrix pada hasil output SPSS terlihat bahwa tabel terbentuk 1 komponen, yang artinya indikator X2.1, X2.2, X2.3, $\mathrm{X} 2.4$, dan X2.5 dikatakan valid dan hanya menjelaskan faktor efektivitas secara berkelanjutan.

c. Uji validitas variabel kepantasan/kelayakan X3

Tabel Component Matrix pada hasil output SPSS, terlihat bahwa terbentuk 2 komponen, sementara yang diharapkan hanya terbentuk 1 komponen, artinya dari keenam indikator yaitu X3.1 sampai dengan X3.6 tersebut ada yang tidak valid. Jadi jika indikator-indikator tersebut valid, maka hanya terbentuk satu komponen yaitu faktor kepantasan / kelayakan. Oleh karena itu proses harus diulang dengan mengeluarkan indikator-indikator yang dianggap tidak valid.

Indikator-indikator yang akan dikeluarkan adalah indikatorindikator yang memiliki MSA (Measure of Sampling Adequancy) yang di bawah 0,5 dengan memperhatikan tabel Anti-Images Matrices pada output SPSS. Perhatikan pada bagian Anti-Images Corelation, bahwa indikator X3.2 memiliki MSA terkecil yaitu 0,642 , dengan demikian indikator tersebut dikeluarkan dari analisis.

Kemudian pada hasil output yang kedua hanya terbentuk 1 komponen, sesuai dengan yang diharapkan artinya dari keenam indikator, masih ada lima indikator yang menjelaskan faktor kepantasan/kelayakan yaitu X3.1, X3.3, X3.4, X3.5, dan X3.6 dinyatakan valid.

d. Uji validitas variabel informasi X4

Tabel Component Matrix pada hasil output SPSS terlihat bahwa tabel terbentuk 1 komponen, yang artinya indikator $\mathrm{X} 4.1, \mathrm{X} 4.2$, dan X4.3 dikatakan valid dan hanya menjelaskan faktor informasi.

e. Uji validitas variabel efisiensi X5

Tabel Component Matrix pada hasil output SPSS terlihat bahwa tabel terbentuk 1 komponen, yang artinya indikator X5.1, X5.2, dan X5.3 dikatakan valid dan hanya menjelaskan faktor efisiensi.

f. Uji validitas variabel efektivitas makanan X6

Tabel Component Matrix pada hasil output SPSS, terlihat bahwa terbentuk 2 komponen, sementara yang diharapkan hanya terbentuk 1 komponen, artinya dari keempat indikator yaitu X6.1 sampai dengan X6.4 tersebut ada yang tidak valid. Jadi jika indikator-indikator tersebut valid, maka hanya terbentuk 1 komponenyaitu faktor efektivitas makanan. Oleh karena itu proses harus diulang dengan mengeluarkan indikator-indikator yang dianggap tidak valid.

Indikator-indikator yang akan dikeluarkan adalah indikatorindikator yang memiliki MSA (Measure of Sampling Adequancy) yang di bawah 0,5 dengan memperhatikan tabel Anti-Images Matrices pada output SPSS. Perhatikan pada bagian Anti-Images Corelation, bahwa indikator X6.4 memiliki MSA terkecil yaitu 0,210, dengan demikian indikator tersebut dikeluarkan dari analisis. 
Kemudian pada hasil output yang kedua hanya terbentuk 1 komponen sesuai dengan yang diharapkan, artinya dari keempat indikator, masih ada tiga indikator yang menjelaskan faktor efektivitas makanan yaitu X6.1, X6.2 dan X6.3 dinyatakan valid.

g. Uji validitas variabel kepuasan Y

Tabel Component Matrix pada hasil output SPSS, terlihat bahwa terbentuk 2 komponen, sementara yang diharapkan hanya terbentuk 1 komponen, artinya dari keenam indikator yaitu Y1 sampai dengan Y6 tersebut ada yang tidak valid. Jadi jika indikator-indikator tersebut valid, maka hanya terbentuk 1 komponen yaitu faktor kepuasan. Oleh karena itu proses harus diulang dengan mengeluarkan indikatorindikator yang dianggap tidak valid.

Indikator-indikator yang akan dikeluarkan adalah indikatorindikator yang memiliki MSA (Measure of Sampling Adequancy) yang di bawah 0,5 dengan memperhatikan tabel Anti-Images Matrices pada output SPSS. Perhatikan pada bagian Anti-Images Corelation, bahwa indikator Y1 memiliki MSA terkecil yaitu 0,361, dengan demikian indikator tersebut dikeluarkan dari analisis.

Kemudian pada hasil output yang kedua dimana Y1 sudah dikeluarkan tetapi masih terlihat 2 komponen, yang berarti masih ada indikator-indikator yang tidak valid (menjelaskan faktor lain selain kepuasan). Dengan demikian proses diulang lagi dengan kembali mengeluarkan indikator yang memiliki MSA (Measure of Sampling Adequancy) dibawah 0,5 atau jika tidak ada yang dibawah
0,5 maka MSA (Measure of Sampling Adequancy) terkecil dikeluarkan dari analisis selanjutnya dengan memperhatikan tabel AntiImages Matrices pada output SPSS. Perhatikan pada bagian Anti-Images Corelation, terlihat bahwa indikator Y2 memiliki MSA terkecil yaitu 0,627 dengan demikian indikator tersebut dikeluarkan dari analisis selanjutnya.

Kemudian pada hasil output yang ketiga dimana Y2 sudah dikeluarkan tetapi masih terlihat 2 komponen lagi, yang berarti masih ada indikator yang tidak valid. Dengan demikian proses diulang lagi dengan kembali mengeluarkan indikator yang memiliki MSA terkecil. Terlihat pada bagian AntiImages correlation bahwa indikator Y3 memiliki MSA terkecil yaitu 0,432 dengan demikian indikator tersebut dikeluarkan dari analisis selanjutnya.

Akhirnya pada proses ini terbentuk 1 komponen, sesuai dengan yang diharapkan, artinya dari 6 indikator terdapat 3 indikator yang menjelaskan faktor kepuasan yaitu Y4, Y5, dan Y6 tersebut dinyatakan valid. 
2. Hasil Uji Reliabilitas

\begin{tabular}{|l|l|l|l|}
\hline Variabel & $\begin{array}{l}\text { Cronbach's } \\
\text { Alpha }\end{array}$ & Nilai Kritis & Keterangan \\
\hline Rasa Kepedulian X1 & 0,868 & 0,60 & Reliabel \\
\hline Efektivitas Berkelanjutan X2 & 0,818 & 0,60 & Reliabel \\
\hline Kepantasan/Kelayakan X3 & 0,805 & 0,60 & Reliabel \\
\hline Informasi X4 & 0,634 & 0,60 & Reliabel \\
\hline Efisiensi X5 & 0,726 & 0,60 & Reliabel \\
\hline Efektivitas-Makanan X6 & 0,741 & 0,60 & Reliabel \\
\hline Kepuasan Y & & & \\
\hline
\end{tabular}

a. Bahwa variabel X1 indikator memiliki nilai Cronbach's Alpha 0,868 yaitu lebih besar dari 0,60 berdasarkan ketentuan diatas maka indikator-indikator dalam variabel $\mathrm{X} 1$ dikatakan reliabel.

b. Bahwa variabel X2 indikator memiliki nilai Cronbach's Alpha 0,818 yaitu lebih besar dari 0,60 berdasarkan ketentuan diatas maka indikator-indikator dalam variabel X2 dikatakan reliabel.

c. Bahwa variabel X3 indikator memiliki nilai Cronbach's Alpha 0,805 yaitu lebih besar dari 0,60 berdasarkan ketentuan diatas maka indikator-indikator dalam variabel X3 dikatakan reliabel.

d. Bahwa variabel X4 indikator memiliki nilai Cronbach's Alpha 0,634 yaitu lebih besar dari 0,60 berdasarkan ketentuan diatas maka indikator-indikator dalam variabel $\mathrm{X} 4$ dikatakan reliabel.

e. Bahwa variabel X5 indikator memiliki nilai Cronbach's Alpha 0,726 yaitu lebih besar dari 0,60 berdasarkan ketentuan diatas maka indikator-indikator dalam variabel X5 dikatakan reliabel.

f. Bahwa variabel X6 indikator memiliki nilai Cronbach's Alpha 0,741 yaitu lebih besar dari 0,60 berdasarkan ketentuan diatas maka indikator-indikator dalam variabel X6 dikatakan reliabel. g. Bahwa variabel $\mathrm{Y}$ dengan Cronbach's Alpha 0,763 yaitu lebih besar dari 0,60 berdasarkan ketentuan diatas maka indikatorindikator dalam variabel $\mathrm{Y}$ dikatakan reliabel.

\section{Hasil Uji Regresi Linier Berganda}

asil uji regresi (koefisien regresi)

\begin{tabular}{|c|c|c|c|c|c|}
\hline \multirow[t]{2}{*}{ Model } & \multicolumn{2}{|c|}{$\begin{array}{l}\text { Unstandardized } \\
\text { Coefficients }\end{array}$} & \multirow{2}{*}{\begin{tabular}{|c|}
$\begin{array}{c}\text { Standardized } \\
\text { Coefficients }\end{array}$ \\
Beta
\end{tabular}} & \multirow[b]{2}{*}{$\mathrm{T}$} & \multirow[b]{2}{*}{ Sig } \\
\hline & B & Std.Error & & & \\
\hline \begin{tabular}{|l} 
(Constant $)$ \\
\end{tabular} & 4.720 & .815 & & 5.794 & .000 \\
\hline Rasa kepedulian & -.041 & .089 & -.051 & -.462 & .645 \\
\hline Efektivitas berkelanjutan & -.033 & .104 & -.035 & -.317 & .752 \\
\hline Kepantasan/kelayakan & .100 & .098 & .114 & 1.019 & .311 \\
\hline Informasi & -.200 & .099 & -.227 & -2.008 & .048 \\
\hline Efisiensi & .060 & .089 & .075 & .670 & .505 \\
\hline Efektivitas-makanan & -.149 & .102 & -.157 & -1.455 & .150 \\
\hline
\end{tabular}

Berdasarkan analisis data di atas diperoleh persamaan sebagai berikut: $\mathrm{Y}=4.720-0.041 \mathrm{X} 1-0.033 \mathrm{X} 2+$ $0.100 X 3-0.200 \mathrm{X} 4+0.060 \times 5-$ 0.149X6

Dari hasil persamaan regresi linier berganda tersebut, dapat diinterpresikan sebagai berikut:

$\mathrm{a}=4.720$ merupakan nilai konstanta, jika nilai X1, X2, X3, X4, X5, dan X6 dianggap 0 maka akan menurunkan nilai Kepuasan sebesar 0.000

$\mathrm{X} 1=-0.041$ artinya variabel rasa kepedulian berpengaruh negatif terhadap kepuasan pasien dan apabila variabel rasa kepedulian meningkat 1 satuan, maka nilai rasa kepedulian akan berpengaruh negatif dengan nilai -0.041. Seberapa tinggi kenaikan rasa kepedulian tidak akan mempengaruhi peningkatan kepuasan pasien.

$\mathrm{X} 2=-0.033$ artinya variabel efektivitas berkelanjutan berpengaruh positif terhadap kepuasan pasien dan apabila variabel efektivitas berkelanjutan meningkat 1 satuan, maka nilai efektivitas berkelanjutan akan meningkat -0.033. Semakin tinggi kenaikan efektivitas berkelanjutan maka semakin tinggi pula pengaruh peningkatan kepuasan pasien. 
$\mathrm{X} 3=0.100$ artinya variabel kepantasan / kelayakan berpengaruh positif terhadap kepuasan pasien dan apabila variabel efektivitas berkelanjutan meningkat 1 satuan, maka nilai kepantasan/kelayakan akan meningkat 0.100. Semakin tinggi kenaikan kepantasan/kelayakan maka semakin tinggi pula pengaruh peningkatan kepuasan pasien.

$\mathrm{X} 4=-0.200$ artinya variabel informasi berpengaruh negatif terhadap kepuasan pasien dan apabila variabel informasi meningkat 1 satuan, maka nilai variabel informasi akan berpengaruh negatif dengan nilai -0.200 . Seberapa tinggi kenaikan variabel informasi tidak akan mempengaruhi peningkatan kepuasan pasien.

$\mathrm{X} 5=0.060$ artinya variabel efisiensi berpengaruh positif terhadap kepuasan pasien dan apabila variabel efisiensi meningkat 1 satuan, maka nilai variabel efisiensi akan meningkat 0.060 . Semakin tinggi kenaikan variabel efisiensi maka semakin tinggi pula pengaruh peningkatan kepuasan pasien. $\mathrm{X} 6=-0.149$ artinya variabel efektivitas-makanan berpengaruh negatif terhadap kepuasan pasien dan apabila variabel efektivitas-makanan meningkat 1 satuan, maka nilai variabel efektivitas-makanan akan berpengaruh negatif dengan nilai 0.149. Seberapa tinggi kenaikan variabel efektivitas-makanan tidak akan mempengaruhi peningkatan kepuasan pasien.
4. Hasil Uji Parsial (Uji T)

Hasil uji signifikansi parsial (Uji t)

\begin{tabular}{|c|c|}
\hline \multirow{2}{*}{ Variabel } & Hasil Uji \\
\cline { 2 - 2 } & Signifikansi \\
\hline Rasa kepedulian & 0.645 \\
\hline Efektivitas secara berkelanjutan & 0.752 \\
\hline Kepantasan/kelayakan & 0.311 \\
\hline Informasi & 0.048 \\
\hline Efisiensi & 0.505 \\
\hline Efektivitas-makanan & 0.150 \\
\hline
\end{tabular}

a. Variabel Rasa kepedulian

Hasil pengujian dengan SPSS

untuk variabel Rasa kepedulian diperoleh nilai $\mathrm{t}$ hitung $=-0.462$ tingkat signifikansi 0.645 . Dengan menggunakan batas signifikansi $(\alpha)$ $=0.05$ maka nilai batas signifikansi $\alpha(0.05)<0.645$, maka hipotesis ditolak. Hal ini berarti variabel rasa kepedulian (X1) tidak mempunyai pengaruh terhadap kepuasan pasien (Y).

b. Variabel Efektivitas secara berkelanjutan

Hasil pengujian dengan SPSS untuk variabel Efektivitas secara berkelanjutan diperoleh nilai t hitung $=-0.317$ tingkat signifikansi 0.752 . Dengan menggunakan batas signifikansi $(\alpha)=0.05$ maka nilai batas signifikansi $\alpha(0.05)<0.752$ maka hipotesis ditolak. Hal ini berarti variabel Efektivitas secara berkelanjuatan (X2) tidak mempunyai pengaruh terhadap kepuasan pasien (Y).

c. Variabel Kepantasan/kelayakan Hasil pengujian dengan SPSS untuk variabel Kepantasan / kelayakan diperoleh nilai $\mathrm{t}$ hitung $=1.019$ tingkat signifikansi 0.311 . Dengan menggunakan batas signifikansi $(\alpha)=0.05$ maka nilai batas signifikansi $\alpha(0.05)<0.311$ maka hipotesis ditolak. Hal ini berarti variabel Kepantasan / kelayakan (X3) tidak mempunyai 
pengaruh terhadap kepuasan pasien (Y).

d. Variabel Informasi

Hasil pengujian dengan SPSS untuk variabel Informasi diperoleh nilai $\mathrm{t}$ hitung $=-2.008$ tingkat signifikansi 0.048 Dengan menggunakan batas signifikansi $(\alpha)$ $=0.05$ maka nilai batas signifikansi $\alpha(0.05)>0.048$ maka hipotesis diterima. Hal ini berarti variabel informasi (X4) mempunyai pengaruh terhadap kepuasan pasien (Y).

e. Variabel Efisiensi

Hasil pengujian dengan SPSS untuk variabel Efisiensi diperoleh nilai $\mathrm{t}$ hitung $=0.670$ tingkat signifikansi 0.505 Dengan menggunakan batas signifikansi $(\alpha)$ $=0.05$ maka nilai batas signifikansi $\alpha(0.05)<0.505$ maka hipotesis ditolak. Hal ini berarti variabel efisiensi (X5) tidak mempunyai pengaruh terhadap kepuasan pasien (Y).

f. Variabel Efektivitas-makanan

Hasil pengujian dengan SPSS untuk variabel Efektivitas-makanan diperoleh nilai $\mathrm{t}$ hitung $=-1.455$ tingkat signifikansi 0.150 . Dengan menggunakan batas signifikansi $(\alpha)$ $=0.05$ maka nilai batas signifikansi $\alpha(0.05)<0.150$ maka hipotesis ditolak. Hal ini berarti variabel Efektivitas-makanan (X6) tidak mempunyai pengaruh terhadap kepuasan pasien (Y).

\section{Hasil Uji Simultan (Uji F)}

\begin{tabular}{|l|l|l|l|l|l|}
\hline Model & $\begin{array}{l}\text { Hus of } \\
\text { Squares }\end{array}$ & Df & $\begin{array}{l}\text { Mean } \\
\text { Squares }\end{array}$ & F & Sig. \\
\hline 1 Regression & 1.805 & 6 & 0.301 & 1.177 & $.327^{2}$ \\
Residual & 20.440 & 80 & 0.255 & & \\
Total & 22.245 & 86 & & & \\
\hline
\end{tabular}

Berdasarkan hasil uji simultan dari tabel diatas ditunjukan bahwa $\mathrm{F}$ hitung sebesar 1.177 dan pada uji $\mathrm{F}$ di atas didapatkan dengan taraf signifikasi $0.05(\operatorname{sig} \alpha 0.327>0.05)$ dapat disimpulkan bahwa faktor Rasa kepedulian (X1), Efektivitas secara berkelanjutan (X2), Kepantasan / kelayakan (X3), Informasi (X4), Efisiensi (X5), Efektivitas-makanan (X6) secara bersama-sama tidak memiliki pengaruh yang signifikan terhadap kepuasan pasien (Y).

6. Hasil Uji Koefisien Determinasi

Hasil uji regeresi (koefisien determinasi)

\begin{tabular}{|l|l|l|l|l|}
\hline Model & R & R Square & $\begin{array}{l}\text { Adjusted } \\
\text { Square }\end{array}$ & $\begin{array}{l}\text { Std. Error of } \\
\text { the Estimate }\end{array}$ \\
\hline 1 & $.285^{\mathrm{a}}$ & .081 & .012 & .505 \\
\hline
\end{tabular}

Pada tabel di atas dapat dilihat bahwa nilai $\mathrm{R}^{2}$ adalah sebesar 0.081 . Hal ini dapat diartikan bahwa variabel independen Rasa kepedulian (X1), Efektivitas secara berkelanjutan (X2), Kepantasan/kelayakan (X3), Informasi (X4), Efisiensi (X5), Efektivitasmakanan (X6), dapat menjelaskan variabel dependen Kepuasan pasien (Y) sebesar $8,1 \%$ sedangkan sisanya diterangkan oleh faktor lain yang tidak diteliti.

\section{Pembahasan}

Pernyataan hipotesis pertama bahwa Rasa kepedulian berpengaruh negatif dan tidak signifikan terhadap kepuasan pasien. Hal ini bisa ditunjukkan dengan nilai signifikansi (P Value) 0.645 yang jauh lebih besar dari pada 0.05 serta nilai koefisien regresi sebesar -0.041. Dapat disimpulkan bahwa rasa kepedulian berpengaruh negatif dan juga tidak signifikan terhadap kepuasan pasien.

Pernyataan hipotesis kedua bahwa Efektivitas secara berkelanjutan berpengaruh negatif dan juga tidak signifikan terhadap kepuasan pasien terbukti. Hal ini dapat ditunjukan dengan nilai signifikansi (P Value) sebesar 0.752 yang jauh diatas 0.05 serta nilai koefisien regresi sebesar -0.033. Hal ini dapat disimpulkan bahwa Efektivitas secara berkelanjutan berpengaruh negatif dan 
juga tidak signifikan terhadap kepuasan pasien.

Pernyataan hipotesis ketiga bahwa Kepantasan/kelayakan berpengaruh positif tetapi tidak signifikan terhadap kepuasan pasien. Hal ini dapat ditunjukan dengan nilai signifikansi ( $\mathrm{P}$ Value) sebesar 0.311 yang jauh diatas 0.05 serta nilai koefisien regresi sebesar 0.100. Hal ini dapat disimpulkan bahwa Kepantasan/kelayakan berpengaruh positif tetapi tidak signifikan terhadap kepuasan pasien.

Pernyataan hipotesis keempat bahwa Informasi berpengaruh negatif tetapi signifikan terhadap kepuasan pasien terbukti. Hal ini dapat ditunjukan dengan nilai signifikansi (P Value) sebesar 0.048 yang lebih kecil dari 0.05 serta nilai koefisien regresi sebesar -0.200 . Hal ini dapat disimpulkan bahwa Informasi berpengaruh negatif tetapi berpengaruh signifikan terhadap kepuasan pasien.

Pernyataan hipotesis kelima bahwa Efisiensi berpengaruh positif dan tidak signifikan terhadap kepuasan pasien terbukti. Hal ini dapat ditunjukan dengan nilai signifikansi ( $\mathrm{P}$ Value) sebesar 0.505 yang jauh diatas 0.05 serta nilai koefisien regresi sebesar 0.060. Hal ini dapat disimpulkan bahwa Efisiensi berpengaruh positif dan tidak signifikan terhadap kepuasan pasien.

Pernyataan hipotesis keenam bahwa Efektivitas-makanan berpengaruh negatif dan tidak signifikan terhadap kepuasan pasien terbukti. Hal ini dapat ditunjukan dengan nilai signifikansi (P Value) sebesar 0.150 yang jauh diatas 0.05 serta nilai koefisien regresi sebesar 0.149. Hal ini dapat disimpulkan bahwa Efektivitas-makanan berpengaruh negatif dan juga tidak signifikan terhadap kepuasan pasien.

\section{KESIMPULAN DAN SARAN}

\section{Kesimpulan}

Berdasarkan analisis regresi linier berganda, maka dapat dilihat bahwa yang paling berpengaruh terhadap variabel kepuasan pasien adalah variabel informasi serta variabel kepantasan/kelayakan, variabel rasa kepedulian berpengaruh negatif dan tidak signifikan, variabel efektivitas berkelanjutan berpengaruh negatif dan tidak signifikan, variabel efisiensi berpengaruh positif tetapi tidak signifikan, variabel efektivitas-makanan berpengaruh negatif dan tidak signifikan.

Pada pengujian hipotesis dengan menggunakan uji F (secara bersamasama atau simultan) dapat dijelaskan bahwa keenam variabel yaitu rasa kepedulian (X1), efektivitas secara berkelanjutan (X2), kepantasan/kelayakan (X3), informasi (X4), efisiensi (X5), efektivitas-makanan (X6) terhadap variabel terikat kepuasan pasien (Y) secara bersama-sama berpengaruh terhadap kepuasan pasien.

Nilai koefisien determinasi $\left(\mathrm{R}^{2}\right)$ yang dihasilkan adalah 0.081. Hal ini berarti sebesar $0.8 \%$ variabel kepuasan pasien dapat dijelaskan oleh variabel rasa kepedulian (X1), efektivitas secara berkelanjutan (X2), kepantasan/kelayakan (X3), informasi (X4), efisiensi (X5), efektivitas-makanan (X6) secara bersamasama (simultan), sedangkan sisanya $92 \%$ dijelaskan oleh variabel lain yang tidak terdapat dalam penelitian ini.

\section{Saran}

1. Puskesmas Mlati II Yogyakarta hendaknya meningkatkan kualitas pelayanan pada dimensi rasa kepedulian, efektivitas secara berkelanjutan, kepantasan/kelayakan, informasi, efisiensi, efektivitasmakanan pada pelayanan jasa Puskesmas Mlati II. Langkah yang dapat dilakukan dengan menjalin 
keakraban dengan pasien, meningkatkan keramahan, kesopanan, menerangkan dengan lebih jelas tentang kondisi hasil tes atau pemeriksaan, mempersilahkan pasien mengajukan pertanyaan, memberikan penjelasan bagi pasien dan menerima masukan atau saran dari pasien.

2. Untuk pasien Puskesmas Mlati II hendaknya lebih selektif dan objektif dalam menilai, memilih dan menggunakan pelayanan Puskesmas tersebut.

\section{DAFTAR PUSTAKA}

Algifari. (2014). Statistika Induktif untuk Ekonomi dan Bisnis. Edisi 3. Yogyakarta.

Djunaidi, Moch. (2006). Analisis Kepuasan Pelanggan Dengan Pendekatan Fuzzy Service Quality Dalam Upaya Meningkatkan Kualitas Pelayanan di Puskesmas Kerjo. Jurnal Ilmiah Teknik Industri. Vol 4 no.3 April 2006.

Lupiyoadi, Rambat. (2014). Manajemen Pemasaran Jasa. Jakarta: Salemba Empat.

Sower, dkk. (2001). The Dimensions of Service Quality for Hospital; Development and Use of the KQCAH Scale. Texas.

Sugiyono. (2014). Metode Penelitian Kuantitatif Kualitatif dan $R \& D$. Bandung: Alfabeta.

Suharyadi, Purwanto. (2010). Statistika untuk Ekonomi dan Keuangan Modern. Edisi 2. Jakarta: Salemba Empat.

Supardi, Sudibyo. (2008). Faktor-faktor yang berhubungan dengan kepuasan pasien rawat jalan dan rawat inap di Puskesmas. Buletin Penelitian.
Tjiptono. (2006). Strategi Pemasaran. Yogyakarta: Andi.

Wulandari. (2011). Analisis Kepuasan Pasien di Rumah Sakit PKU Muhammadiyah Yogyakarta. Yogyakarta: Skripsi.

\section{.}

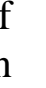

